\title{
Nutritional evaluation of camel browse vegetations at Mithi district of Pakistan
}

\author{
Asad Ali Khaskheli ${ }^{*}$, Gulfam Ali Mughal ${ }^{1}$, Gul Bahar Khaskheli ${ }^{2}$, \\ Allah Jurio Khaskheli ${ }^{3}$, Arshad Ali Khaskheli ${ }^{1}$, Arab Khan Lund ${ }^{4}$, Turab \\ Ali Kaurejo ${ }^{5}$, Muhammad Usman ${ }^{1}$, Mohsin Khan ${ }^{1}$ and Muhammad \\ Arshad Azeem ${ }^{1}$ \\ 1. Department of Animal Nutrition, Sindh Agriculture University, Tandojam-Pakistan \\ 2. Department of Animal Products Technology, Sindh Agriculture University, Tandojam-Pakistan \\ 3. Department of Biotechnology, Sindh Agriculture University, Tandojam-Pakistan \\ 4. Shaheed Benazir Bhutto University of Veterinary and Animal Sciences, Sakrand-Pakistan \\ 5. Department of Livestock Management, Sindh Agriculture University, Tandojam-Pakistan \\ *Corresponding author's email: khaskhelias@gmail.com \\ Citation \\ Asad Ali Khaskheli, Gulfam Ali Mughal, Gul Bahar Khaskheli, Allah Jurio Khaskheli, Arshad Ali Khaskheli, Arab \\ Khan Lund, Turab Ali Kaurejo, Muhammad Usman, Mohsin Khan and Muhammad Arshad Azeem. Nutritional \\ evaluation of camel browse vegetations at Mithi district of Pakistan. Pure and Applied Biology. Vol. 8, Issue 3, \\ pp2051-2064. http://dx.doi.org/10.19045/bspab.2019.80150
}

\begin{tabular}{llll}
\hline \hline Received: 28/05/2019 & Revised: 13/07/2019 & Accepted: 23/07/2019 & Online First: 26/07/2019 \\
\hline
\end{tabular}

\section{Abstract}

Investigation was carried out at the department of Animal Nutrition, Sindh Agriculture University, Tandojam during the year 2018. Study was themed to monitor and assess major nutrients in different camel browse vegetations over Mithi. Results of present study indicated Salvadora oleiodes pertaining significantly $(\mathrm{p}<0.05)$ highest moisture $(64.45 \%)$ content and Calligonum polygonoides the lowest (6.37\%) amongst all vegetations, while dry matter content appeared vice versa. Acacia jacquemontii contained prominently rich $(94.75 \%)$ and Salvadora oleiodes possessed considerably $(\mathrm{p}<0.05)$ poor $(59.40 \%)$ concentration of total organic matter, while total inorganic matter was found vice versa. Crude protein in Capparis deciduas was recorded considerably $(\mathrm{p}<0.05)$ high (21.94\%) and in Acacia nilotica it was low (6.68\%). Senegalia senegal (3.10\%), Acacia jacquemontii (2.45\%), Simmondsia chinensis (0.95\%) and Salvadora oleiodes (0.50\%) possessed prominently linear trend for ether extract. Nitrogen free extract was considerably high $(\mathrm{p}<0.05)$ in Calligonum polygonoides $(62.04 \%)$ and significantly $(\mathrm{p}<0.05)$ low in Salvadora oleiodes (24.94\%), while Ziziphus nummularia $(48.95 \%)$ varied significantly $(\mathrm{p}<0.05)$ from Sesamum indicum (47.95\%). Crude fiber concentration was abundant in Acacia jacquemontii. Concentration of total carbohydrate level was prominently high $(\mathrm{p}<0.05)$ in Calligonum polygonoides $(81.19 \%)$ and in Salvadora oleiodes it was low (45.74\%). Present study concludes that the Mithi district do not support the moisture content but it do have positive influence on the dry matter, inorganic matter and ether extract contents, whereby Senegalia senegal appeared considerably rich in organic matter, Cordia sinensis (Linn.) in total inorganic/mineral matter and Calligonum polygonoides in carbohydrate contents.

Keywords: Browsing; Nutrient; Shurbs; Trees; Vegetation 


\section{Introduction}

Mithi is considered as the capital of Tharparkar district of Sindh province in Pakistan. Due to sandy land this city has a very poor agriculture production which negatively influences the livestock performance. Livestock animals especially camels in the vicinity of this city use a wide range of non-conventional vegetations which naturally grow in the respective region [1]. Camels are very selective regarding their diet intake, they prefer to browse broad spectrum of plants like shrubs, trees, halophytic (salty) and hard-thorny plants though naturally grow in the desert and semi-arid areas. They generally browse leaves, young twigs/shoots, fruits, flowers and pods. Under normal circumstances camels have ability to choose their forages efficiently, browse more on trees than grasses [2]. Camels' fondness towards such plants is due to their peculiar anatomical structures such as the mobile and prehensile split upper lip, long tongue, stretched neck and extended head. These all specialized anatomical features make them preferentially browsers than grazers $[3,4]$. Another important feature of camels' browsing habits is that they are not in direct competition with other domestic animals excepting goat. The greatest competition for feed resources is found between camels and goats, with $47.5 \%$ dietary overlap in the dry season and $12.4 \%$ in the green (wet) season [5].

It has been reported that the forage quality do have significant influence on the feeding pattern of the camels, whereby adverse pasture status acts as restrictive factor for nutrients and total dry matter intake. Total dry matter intake by camel needs to be approximately $4 \%$ of body weight and that might be satisfied by browsing 15 or more hours per day. Generally, a mature camel weighing $650 \mathrm{Kg}$ require approx. $26 \mathrm{Kg}$ of dry matter which may be satisfied by taking
80 to $100 \mathrm{Kg}$ of plants with high moisture contents [6]. Under open range conditions camels are able to exploit wide variety of plants by rapidly moving from one feeding station to the next. Wherever preferred or selected vegetations are plentiful their ingestion rate remains rapid but on thorny species having little leaves, ingestion rate declines. Camels rarely over browse as they constantly move and take only small portions of each plant. They prefer to browse early in the morning and late afternoon, which are the coolest times of day for feeding [7].

As mentioned earlier, the chemical composition has considerable impact on the camel preference for vegetations and eventually their production quality and quantity. Keeping in view these aspects multiple studies although have already been carried out on the composition of camel browse vegetations in the different parts of Pakistan, as [8] reported the variations in nutritive value of locally available 10 free rangeland grasses identified in valley of Chagharzai in Bunair district, Malakand Division (NWFP) and observed the variation in nutrients composition, [9] studied nutritional composition of some top fodder tree leaves and shrubs of district dir (lower), Pakistan whereby 13 tree leaves, shrubs and browse plants such as Eleusine coracana, Cyperus rotundus, Sorghum halepense, Tike mimosa, Populus Euphratica, Morus nigra, Sorghum bicolor, Oryza sativa, Prunus persica, Cynodon dactylo, Cotton seed cake, Ficus carica and wheat straw were analyzed for proximate composition. [10] assessed the nutritional composition of some indigenous and exotic rangeland grass species whereby Ten native and exotic grass species were analyzed to find the nutritional characteristics such as moisture, protein, crude fiber and ash content on dry matter percent basis in the field area of department of Forestry, Range Management and 
Wildlife, University of Agriculture, Faisalabad (UAF). Further, compositional variation in some fodder species from Harboi rangeland, Kalat, Balochistan was also reported whereby grasses found high in dry matter (DM), Crude fiber (CF), carbohydrates, nitrogen free extract (NFE), neutral detergent fiber (NDF), acid detergent fiber (ADF) and hemicelluloses than shrubs, and vice versa for crude protein $(\mathrm{CP})$, ether extract (EE), nitrogen $(\mathrm{N})$, gross energy (GE), acid detergent lignin (ADL) contents [11]. But unfortunately in Sindh province of Pakistan such kinds of studies have rarely been invested. Especially in the Mithi district such type of investigation has never been carried out yet. Current study was therefore planned in order to evaluate the nutritional composition of different camel browse vegetation in Mithi district of Pakistan.

\section{Materials and methods}

\section{Location of study}

The main place for conducting the research on camel browse vegetations was the Laboratory of Animal Nutrition, Faculty of Animal Husbandry and Veterinary Sciences, Sindh Agriculture University, Tandojam. Further, five different villages of Mithi district of Sindh province were included to monitor and collect samples of camel browse vegetations for current study.

\section{Experimental procedure}

Present research was conducted during the year 2018 whereby investigation was subjected into two phases. In the first phase, comprehensive survey was performed at different villages of Mithi district of Sindh province in order to gather the data regarding availability of different camel browse vegetations. In the second phase of study major nutrients among camel browse vegetations grown in the vicinity of district Mithi were analyzed. A total of 13 different types of camel browse vegetations were sampled. To have replicated data, composite sampling was performed. All the samples were brought to the Laboratory of Animal Nutrition, Sindh Agriculture University Tandojam for further analysis. Sample were dried under Air air Oven $\left(65^{\circ} \mathrm{C}\right)$ and stored till analysis. For the examination of dry matter and inorganic/mineral (ash) matter contents, fresh samples were processed. Moreover, the data on major nutritional variables like moisture, dry matter, total organic matter, ether extract, crude fiber, crude protein, nitrogen free extract and total carbohydrate was gathered.

\section{Analysis of major nutrients among camel browse vegetations \\ Moisture content}

Moisture content was determined by evaporation method [12]. The washed aluminum dishes encoded with appropriate codes were moisture off in a hot air oven at $100 \pm 1^{\circ} \mathrm{C}$ for one hour. Sample of each camel browse vegetation $(2 \mathrm{~g})$ was measured in pre-weighed empty dried aluminum dish and kept in hot air oven at $105 \pm 1{ }^{\circ} \mathrm{C}$ for approximately $24 \mathrm{hrs}$. It was then desiccated, weighed and re-dried in the hot air oven for further $30 \mathrm{~min}$. It was again desiccated and weighed as before. The process of drying, desiccating and weighing were repeated till constant weight. The observed weight of sample with dish, dried sample with dish and empty dish were placed in the following formula was used to compute the percent of moisture content in camel browse vegetations:

\footnotetext{
$\%$ Moisture content $=$ Weight of dish with sample - Weight of dish with dried sample $\times 100$ Weight of dish with sample - Weight of empty dish
} 


\section{Dry matter content}

Dry matter of samples was analyzed using similar method as for moisture. However, observations noted at each step were placed in the following formula to compute the percent of dry matter content in camel browse vegetations:

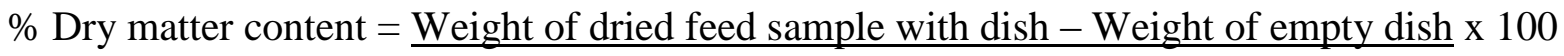
Weight of dish with sample - Weight of empty dish

\section{Total organic matter}

Total organic matter among camel browse vegetations was computed by difference method. Percent of inorganic/mineral (ash) matter was subtracted from Hundred to calculate the percent of total organic matter (i.e. \%Total organic matter $=100-$ \%Inorganic matter)

\section{Ether extract content}

Ether extract content was determined through Soxhlet method [12]. Ground sample $(2 \mathrm{~g})$ in thimble was extracted with diethyl ether $(200 \mathrm{ml})$ into pre-weighed clean and dry fat beaker for six hrs. Fat Beaker was transferred to the Hot air oven to evaporate the residual ether. It was placed in desiccator and finally weighed. The percent of ether extract was calculated by using formula given below:

$\%$ Ether extract $($ DM basis $)=($ Weight of breaker with fat residue - Empty weight of breaker $) \times 100$ Initial sample weight

\section{Crude protein content}

Crude protein content was computed from nitrogen content present in the sample, whereby it was firstly processed using Kjeldhal method. Sample (1g) was measured in Kjeldhal flask to which copper sulfate $(0.2 \mathrm{~g})$ and sodium sulfate $(2 \mathrm{~g})$ as catalyst were added. Further, sulfuric acid $(25 \mathrm{ml})$ as an oxidizing agent was delivered into similar flask, and digested in MicroKjeldhal digester till solution became transparent. It was transferred into volumetric flask $(250 \mathrm{ml})$, and made up to mark with distilled water. Diluted sample (5ml) was distilled with $40 \%$ Sodium Hydroxide $(5 \mathrm{ml})$ using Micro-Kjeldhal distillation unit, where steam was distilled over 2 percent boric acid $(5 \mathrm{ml})$ containing Phenolphetalin as an indicator for 3 minutes. The ammonia trapped in boric acid was titrated with $0.01 \mathrm{~N} \mathrm{HCl}$, and the volume of $\mathrm{HCl}$ used was recorded. Parallel to this, a blank sample though containing only distilled water instead of sample was processed in similar manner as mentioned above. In the last, percent of nitrogen content present in camel browse vegetations was computed using formula given below:

$\% \mathrm{~N}=1.4$ (Titrated sample value - Titrated blank sample value) x Normality of HCL x 250

Sample weight $\mathrm{x}$ Volume of sample used for distillation

Moreover, the percent of crude protein content in sample was calculated by multiplying the Nitrogen content obtained in the above procedure with conversion factor of 6.25 . (i.e. \% Crude protein $=$ Nitrogen percent $\times 6.25$ )

\section{Crude fiber content}

Crude fiber was determined using VanSoest method [12]. Ether extracted sample $(2 \mathrm{~g})$ was transferred to the $600 \mathrm{ml}$ beaker. Preheated $\mathrm{H}_{2} \mathrm{SO}_{4}$ having normality $0.2 \mathrm{~N}$ was delivered into the beaker $(200 \mathrm{ml})$ and the 
condenser was placed on the beaker, and tap water was started. Solution was gently boiled for about 30min. Contents of beaker were filtered through buchner funnel, beaker was rinsed with $50 \mathrm{ml}$ of boiling water, and washed through buchner. Washing was repeated until the residues appeared neutral. Residues were transferred back into the beaker. Boiled $\mathrm{NaOH}$ having normality $0.3 \mathrm{~N}$ was transferred into the beaker $(200 \mathrm{ml})$ and boiled exactly for $30 \mathrm{~min}$. Contents were filtered as above and washed with $25 \mathrm{ml}$ of boiling $\mathrm{H}_{2} \mathrm{SO}_{4}(0.2 \mathrm{~N})$ and then with $50 \mathrm{ml}$ $\mathrm{H}_{2} \mathrm{O}$. The residues were dried at $65^{\circ} \mathrm{C}$ for about $24 \mathrm{hrs}$ and weighed. The residues were transferred into a clean, labeled and preweighed crucible and placed under muffle furnace $\left(600^{\circ} \mathrm{C}\right)$ for $4 \mathrm{hrs}$. Crucible containing sample was cooled in the desiccator and weighed using analytical weight balance. The observations recorded during this procedure were fixed in the following formula to compute the crude fiber percent.

\section{$\%$ Crude fiber $=$ Dry weight of residues before ashing - Weight of residues after ashing $\times 100$ Initial weight of sample}

\section{Nitrogen free extract content}

Nitrogen free extract in different camel browse vegetations was analyzed by difference method, whereby sum of ether extract; crude protein; crude fiber and ash content was subtracted from Hundred i.e. Nitrogen free extract $(\%)=100-(\%$ crude protein $+\%$ ether extract $+\%$ crude fiber $+\%$ mineral/ash content)

\section{Total carbohydrate content}

Percent of nitrogen free extract and crude fiber was summed together to calculate the total carbohydrate content in different camel browse vegetations (i.e. \% Total carbohydrate $=\%$ Nitrogen free extract $+\%$ crude fiber).

\section{Analysis of inorganic/mineral matter}

Inorganic/mineral (Ash) matter content was examined using Gravimetric method (AOAC, 2000) whereby sample $(2 \mathrm{~g})$ in preweighed crucible was ignited in muffle furnace $\left(600^{\circ} \mathrm{C}\right)$ for $6 \mathrm{hrs}$, and thereafter, it was desiccated for One hour and the weight was recorded. The concentration of ash was calculated by applying the following formula on observations recorded in each step.

$\%$ Inorganic/mineral $($ ash $)$ matter $=\frac{\text { Weight of crucible with ignited sample }- \text { Empty weight of crucible }}{\text { Initial weight of sample }} 100$

\section{Results and discussion}

Moisture and dry matter content

Camel browse vegetations like Acacia nilotica, Ziziphus nummularia, Acacia jacquemontii, Prosopis juliflora, Cyamopsis tetragonoloba, Cordia sinensis (Linn.), Prosopis cineraria, Capparis deciduas, Sesamum indicum, Senegalia Senegal, Simmondsia chinensis and Calligonum polygonoides sampled from Mithi district were analyzed for moisture, dry matter, organic and inorganic/mineral matters and results are depicted in the (Table
1). Moisture content varied significantly $(p<0.05)$ plant to plant. Salvadora oleiodes pertained significantly $(\mathrm{p}<0.05)$ highest moisture content $(64.45 \%)$ and Calligonum polygonoides $(6.37 \%)$ the lowest among all the plants studied in the present study, while the dry matter content appeared vice versa to the moisture content, whereby Calligonum polygonoides revealed the highest dry matter percent (93.63) and the Salvadora oleiodes the lowest $(35.55 \%)$. Results of rest of the plants revealed that only four plants were above the average level of moisture content 
(32.96\%) of all the plants, where it was significantly high in Cordia sinensis (Linn.) $(58.55 \%)$ followed by Prosopis cineraria (56.55\%), Capparis deciduas $(55.95 \%)$ and Prosopis juliflora (44.55\%). The moisture content in Acacia nilotica (27.95\%) followed by Simmondsia chinensis (25.45\%), Senegalia senegal (24.05\%), Acacia jacquemontii (23.05\%), Ziziphus nummularia (20.45\%), Cyamopsis tetragonoloba (12.15\%) and Sesamum indicum (8.95\%) appeared below the level of average (32.86\%). Similarly dry matter content in rest of the plants also appeared vice versa to moisture content, whereby Sesamum indicum (91.05), Cyamopsis tetragonoloba (87.85), Ziziphus nummularia (79.55), Acacia jacquemontii (76.95), Senegalia senegal (75.95), Simmondsia chinensis (74.55), Acacia nilotica (72.05) recorded above and Prosopis juliflora (55.45), Capparis deciduas (44.05), Prosopis cineraria (43.45) and Cordia sinensis (Linn.) (41.45) below from the average level of dry matter computed for all plants (67.04\%). For instance, result regarding the Calligonum polygonoides in the present sudy is very much related with the findings of [13] who reported $91 \%$ dry matter content in Calligonum polygonoides. On the other hand, findings of dry matter contents of Cyamopsis tetragonoloba and Sesamum indicum revealed strong negative correlation with the results reported for degummed guar (Cyamopsis tetragonoloba L.) seeds from Mediterranean area [14]. However, it was not supported by [14] who otherwise observed somewhat lower concentration from the current study. Regarding the dry matter content in Senegalia senegal under current study, results found inconsistent with that of [15] who reported $40.8 \%$ dry matter in Senegalia senegal. In case of Ziziphus nummularia, dry matter content in current investigation appeared in agreement with different studies
[16-18]. Moreover, percent of dry matter in Capparis deciduas recorded in the present study found dissimilar with the reported results of [19] who reported $\sim 1.7$ fold higher dry matter in Capparis deciduas. Nevertheless, findings of dry matter in Salvadora oleiodes found comparble with the study of [20] who reported $61.6 \%$ dry matter in Salvadora oleiodes at Darazinda FRDI Khan, Pakistan. Percent of dry matter content of Acacia nilotica did not match with that of reported by [18] i.e $60.4 \pm 1.9 \%$. Moisture content of Acacia nilotica, Ziziphus nummularia, Capparis deciduas, Senegalia Senegal in the current study did not appear in line with that of reported studies of different authors [16, 21-25] and found quit different, while in Prosopis juliflora, Salvadora oleiodes, Cordia sinensis (Linn.) and Calligonum polygonoides it was in accordance with different reported studies [13, 20, 26-28].

Further results shown in (Table 1) indicates that the Acacia jacquemontii (94.75\%) contained prominently $(\mathrm{p}<0.05)$ rich and Salvadora oleiodes (59.40\%) possessed considerably poor concentration of total organic matter compared to Senegalia senegal (94.05\%), Calligonum polygonoides (93.80\%), Capparis deciduas (91.95\%), Simmondsia chinensis (91.95\%), Prosopis cineraria (90.75\%), Ziziphus nummularia (90.65\%), Sesamum indicum (90.65\%), Cyamopsis tetragonoloba (89.35\%), Prosopis juliflora (87.70\%), Acacia nilotica (72.85\%), Cordia sinensis (Linn.) (65.25\%). Senegalia senegal (94.05\%) and Calligonum polygonoides $(93.80 \%)$ did not show any prominent difference in total organic matter but contrast to other camel browse vegetations their total organic matter varied significantly $(\mathrm{p}<0.05)$. Similarly, organic matter in each of Capparis deciduas $(91.95 \%)$ versus Simmondsia chinensis (91.95\%), Ziziphus nummularia (94.05\%) versus Calligonum polygonoides (93.80\%), 
Prosopis cineraria $(90.75 \%)$ versus Ziziphus nummularia $(90.65 \%)$ and Sesamum indicum $(90.65 \%)$ did not vary prominently, but these sets acquired significant $(\mathrm{p}<0.05)$ variation compare to each other as well as to all other camel browse vegetations. The level of organic matters recorded in the present study for Senegalia senegal, Calligonum polygonoides, Acacia jacquemontii, Capparis deciduas, Prosopis juliflora, Prosopis cineraria and Ziziphus nummularia found relatively in accordance with that of reported in different studies [13, 15-17, 24, 29-31]. Nevertheless, slight variation occurred among them. This minor difference may be concerned with the environmental changes or variety distinction. However, the level of organic matter in Acacia nilotica, Salvadora oleiodes and Cordia sinensis (Linn.) in current study totally disagreed with that of stated by different authors $[17,20,22,23$, 26].

Concerning inorganic/mineral matter (Table 1), Salvadora oleiodes $(40.60 \%)$ possessed significantly $(\mathrm{p}<0.05)$ more level and Acacia jacquemontii (5.25\%) the less. Further, inorganic/mineral matter in Salvadora oleiodes (40.60\%), Cordia sinensis (Linn.) (34.75\%) and Acacia nilotica (27.15\%) appeared higher compared to average level calculated for all the plants examined in present investigation. Inorganic/mineral matter in Ziziphus nummularia $(9.35 \%)$ versus Sesamum indicum (9.35\%) versus Prosopis cineraria (9.25\%), Capparis deciduas $(8.05 \%)$ versus Simmondsia chinensis (8.05\%), and Calligonum polygonoides $(6.20 \%)$ versus Senegalia senegal (5.95\%) although did not vary considerably $(\mathrm{p}>0.05)$, but varied significantly $(\mathrm{p}<0.05)$ to each other. Similarly, Capparis deciduas (8.05\%) versus Simmondsia chinensis $(8.05 \%)$ had no prominent $(\mathrm{p}>0.05)$ difference compared to each other but against other camel browse vegetations they varied significantly $(\mathrm{p}<0.05)$. Present results of inorganic/mineral matter in Cordia sinensis (Linn.), Senegalia senegal, Salvadora oleiodes and Acacia nilotica did not appear in accordance with that of reported in different studies $[24,25,27,32]$. While findings regarding inorganic matter in Prosopis cineraria, Prosopis juliflora, Capparis deciduas, Calligonum polygonoides, Acacia jacquemontii and Ziziphus nummularia in the current study found in line with that of reported by different authors [13, 16, 17, 25 27, 29, 30].

\section{Crude protein content}

Crude protein content of different camel browse vegetations sampled from Mithi district were assessed, and results are depicted in (Figure 1). It was noted that crude protein in Capparis deciduas $(21.94 \%)$ was considerably high $(\mathrm{p}<0.05)$ and in Acacia nilotica (6.68\%) it was significantly low $(\mathrm{p}>0.05)$ compared to Ziziphus nummularia (15.36\%), Acacia jacquemontii (15.36\%), Sesamum indicum (15.21\%), Salvadora oleiodes (13.17\%), Prosopis juliflora (12.45\%), Prosopis cineraria (12.12\%), Senegalia senegal (11.97\%), Calligonum polygonoides (11.26\%), Simmondsia chinensis (11.20\%), Cordia sinensis (Linn.) (10.54\%) and Cyamopsis tetragonoloba (10.53\%).

Further results revealed that Ziziphus nummularia (15.36\%) versus Acacia jacquemontii (15.36\%) versus Sesamum indicum (15.21\%), Salvadora oleiodes (13.17\%) versus Acacia nilotica (6.68\%), Prosopis juliflora (12.45\%) versus Prosopis cineraria $(12.12 \%)$ versus Senegalia senegal (11.97\%), Calligonum polygonoides $(11.26 \%)$ versus Simmondsia chinensis (11.20\%), and Cordia sinensis (Linn.) (10.54\%) versus Cyamopsis tetragonoloba (10.53\%) appeared statistically non-significant $(\mathrm{p}>0.05)$, but each set existed significantly $(p<0.05)$ 
different from one another. Crude protein content in Capparis deciduas recorded in the present study found statistically similar to that of reported by [19], while [25] did not support it, their findings looks quite dissimilar from the present results.

Table 1. Evaluation of moisture and dry matter content in camel browse vegetations sampled from Mithi district

\begin{tabular}{|c|c|c|c|c|}
\hline \multirow[b]{2}{*}{$\begin{array}{l}\text { Camel browse } \\
\text { Vegetations }\end{array}$} & \multirow[b]{2}{*}{$\begin{array}{l}\text { Moisture } \\
(\%)\end{array}$} & \multicolumn{3}{|c|}{ Dry matter } \\
\hline & & $\begin{array}{l}\text { Total } \\
(\%)\end{array}$ & $\begin{array}{c}\text { Organic matter } \\
\text { (\% over dry matter) }\end{array}$ & $\begin{array}{c}\text { Inorganic matter } \\
\text { (\% over dry matter) }\end{array}$ \\
\hline Acacia nilotica & $27.95^{\mathrm{f}}$ & $72.05^{\mathrm{h}}$ & $72.85^{\mathrm{g}}$ & $27.15^{\mathrm{c}}$ \\
\hline Ziziphus nummularia & $20.45^{j}$ & $79.55^{\mathrm{d}}$ & $90.65^{\mathrm{d}}$ & $9.35^{\mathrm{f}}$ \\
\hline Acacia jacquemontii & $23.05^{\mathrm{i}}$ & $76.95^{\mathrm{e}}$ & $94.75^{\mathrm{a}}$ & $5.25^{\mathrm{i}}$ \\
\hline Prosopis juliflora & $44.55^{\mathrm{e}}$ & $55.45^{\mathrm{i}}$ & $87.70^{f}$ & $12.30^{\mathrm{d}}$ \\
\hline Cyamopsis tetragonoloba & $12.15^{\mathrm{k}}$ & $87.85^{\mathrm{c}}$ & $89.35^{\mathrm{e}}$ & $10.65^{\mathrm{e}}$ \\
\hline Cordia sinensis (Linn.) & $58.55^{\mathrm{b}}$ & $41.45^{1}$ & $65.25^{\mathrm{h}}$ & $34.75^{\mathrm{b}}$ \\
\hline Prosopis cineraria & $56.55^{\mathrm{c}}$ & $43.45^{\mathrm{k}}$ & $90.75^{\mathrm{d}}$ & $9.25^{\mathrm{f}}$ \\
\hline Salvadora oleiodes & $64.45^{\mathrm{a}}$ & $35.55^{\mathrm{m}}$ & $59.40^{\mathrm{i}}$ & $40.60^{\mathrm{a}}$ \\
\hline Capparis deciduas & $55.95^{\mathrm{d}}$ & $44.05^{\mathrm{j}}$ & $91.95^{\mathrm{c}}$ & $8.05^{\mathrm{g}}$ \\
\hline Sesamum indicum & $8.95^{1}$ & $91.05^{\mathrm{b}}$ & $90.65^{\mathrm{d}}$ & $9.35^{\mathrm{f}}$ \\
\hline Senegalia senegal & $24.05^{\mathrm{h}}$ & $75.95^{\mathrm{f}}$ & $94.05^{b}$ & $5.95^{\mathrm{h}}$ \\
\hline Simmondsia chinensis & $25.45^{\mathrm{g}}$ & $74.55^{\mathrm{g}}$ & $91.95^{\mathrm{c}}$ & $8.05^{\mathrm{g}}$ \\
\hline Calligonum polygonoides & $6.37^{\mathrm{m}}$ & $93.63^{\mathrm{a}}$ & $93.80^{\mathrm{b}}$ & $6.20^{\mathrm{h}}$ \\
\hline LSD $(0.05)$ & 0.147 & 0.147 & 0.2746 & 0.1271 \\
\hline $\mathrm{SE} \pm$ & 0.068 & 0.068 & 0.1271 & 0.2746 \\
\hline
\end{tabular}

$\operatorname{LSD}(0.05)=0.6375$

$\mathrm{SE} \pm 0.2951$

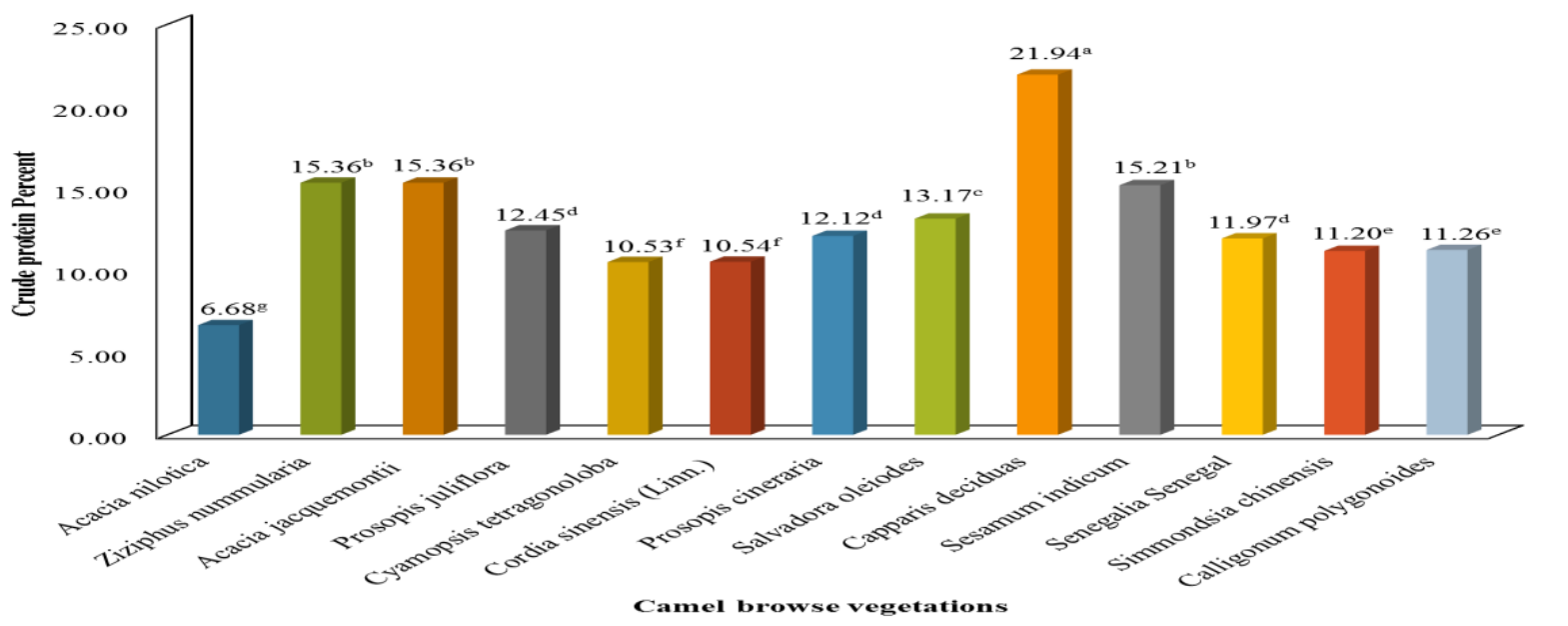

Figure 1. Evaluation of crude protein content in camel browse vegetations sampled from Mithi district

The level of crude protein content in Salvadora oleiodes appeared dissimilar with that of observed by $[20,32]$ but their concentration seem to be somewhat close to reported findings of [25]. The level of crude protein contents in Ziziphus nummularia, Acacia nilotica and Prosopis cineraria in present findings existed in agreement with that of reported results of different authors $[16,17]$. Further, the level of crude protein 
content in Prosopis juliflora, Prosopis cineraria and Acacia jacquemontii are very much different compared to that of reported in different studies [24, 27, 30]

\section{Ether extract content}

Ether extract content of different camel browse vegetations sampled from Mithi district were examined, and results are dipicted in the (Figure 2). It was observed the ether extract in Acacia nilotica $(3.55 \%)$ and Sesamum indicum (3.45\%) existed relatively similar $(\mathrm{p}>0.05)$ to each other and found significantly $(\mathrm{p}<0.05)$ different from all other camel browse vegetations at Mithi district examined under present investigation. Futher, results showed that Senegalia senegal (3.10\%), Acacia jacquemontii (2.45\%), Simmondsia chinensis $(0.95 \%)$ and Salvadora oleiodes $(0.50 \%)$ possessed prominently linear trend for ether extract.

Differences in ether extract between Ziziphus nummularia (1.85\%) versus Cordia sinensis (Linn.) (1.85\%), Prosopis juliflora (1.55\%) versus Prosopis cineraria (1.55\%), and between Capparis deciduas (1.45\%) versus Prosopis juliflora (1.55\%) verus Prosopis cineraria (1.55\%) versus
Calligonum polygonoides (1.35\%) existed statistically non-significant $\quad(\mathrm{p}>0.05)$. Likewise, Calligonum polygonoides although did not possess prominent $(\mathrm{p}>0.05)$ differences in ether extract level of Capparis deciduas (1.45\%) and Cyamopsis tetragonoloba $(1.25 \%)$ but compared to that of other camel browse vegetations it was significantly different $(\mathrm{p}<0.05)$. Similarly, Cyamopsis tetragonoloba (1.25\%) showed no significant $(\mathrm{p}>0.05)$ variation in ether extract level compared to a Calligonum polygonoides $(1.35 \%)$ but it was considerably $(p<0.05)$ different from other camel browse vegetations. The concentration of ether extract content in Senegalia senegal, Cordia sinensis (Linn.), Prosopis juliflora, Acacia nilotica, Capparis deciduas, Prosopis cineraria, Calligonum polygonoides and Ziziphus nummularia observed in the current study were in line with that of reported in different studies [13, $16,17,21-23,25,27,29,33]$, while percent of ether extract in Salvadora oleiodes and Acacia jacquemontii recorded in current study found somewhat different from reported studies $[\mathbf{2 0}, \mathbf{2 4}, \mathbf{3 0}]$.

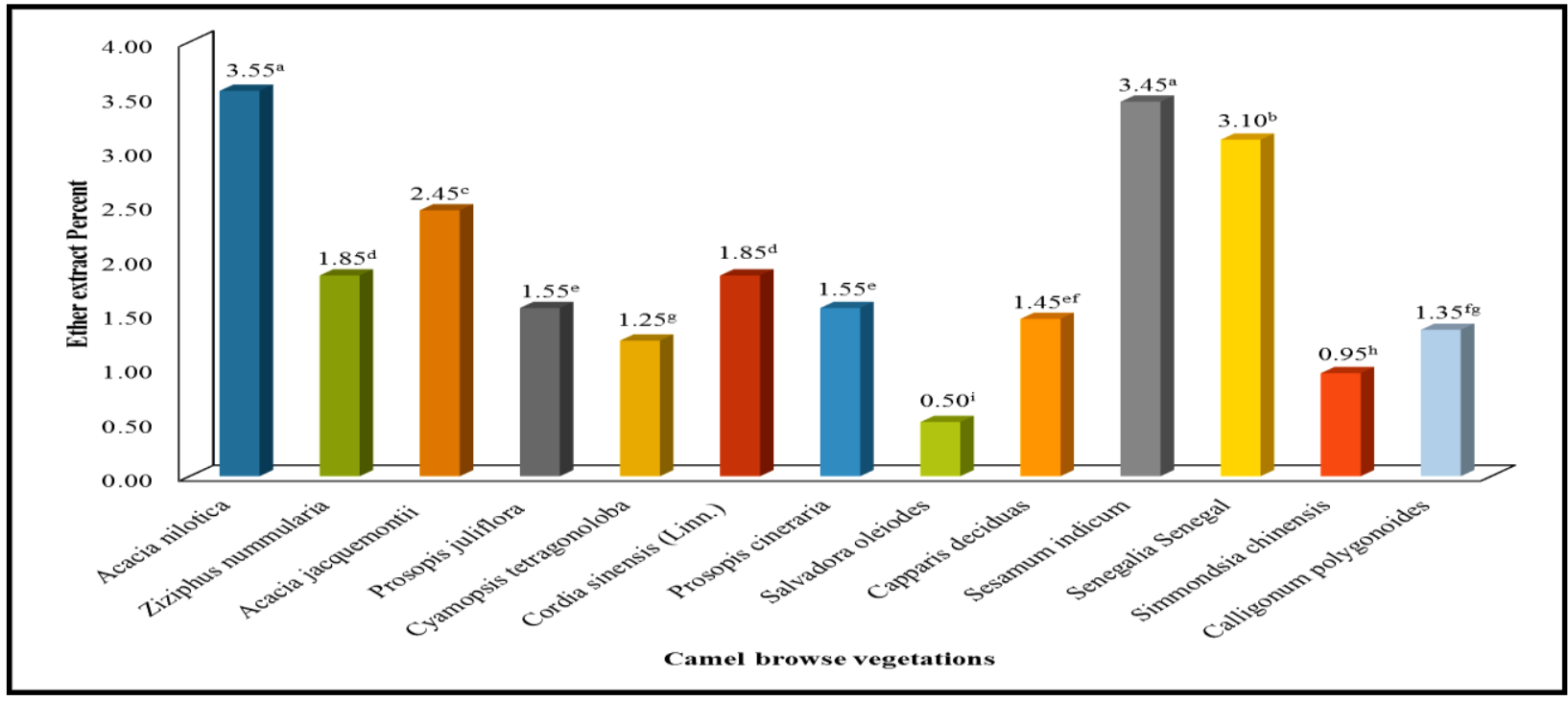

Figure 2. Evaluation of ether extract content in camel browse vegetations sampled from Mithi district 


\section{Carbohyderate contents}

Camel browse vagetations from Mithi district were assessed for nitrogen free extract, crude fiber and total carbohydrate contents and results are given in the (Table 2). It was noted that the nitrogen free extract in camel browse vegetations at Mithi varied plant to plant. It was recored considerably high $(\mathrm{p}<0.05)$ in Calligonum polygonoides $(62.04 \%)$ and significantly low in Salvadora oleiodes (24.94\%) compared to that of in Senegalia senegal (58.64\%), Cyamopsis tetragonoloba (58.43\%), Simmondsia chinensis (56.00\%), Prosopis cineraria (55.49\%), Prosopis juliflora (49.75\%), Ziziphus nummularia (48.95\%), Acacia jacquemontii (48.40\%), Sesamum indicum (47.95\%), Capparis deciduas (40.92\%), Acacia nilotica (39.17\%) and Cordia sinensis (Linn.) (32.96\%). Further, results showed that there was no prominent $(\mathrm{p}>0.05)$ variation in nitrogen free extract of Senegalia senegal versus Cyamopsis tetragonoloba and Simmondsia chinensis versus Prosopis cineraria. Regardless nitrogen free extract in Ziziphus nummularia varied significantly $(p<0.05)$ from that of recorded in Sesamum indicum but concentration in both of these plants noted realtively similar ( $p>0.05$ ) to that of found in Acacia jacquemontii. The concentration of nitrogen free extract in Prosopis juliflora, Capparis deciduas, Acacia nilotica and Cordia sinensis (Linn.) recorded in significantly $(\mathrm{p}<0.05) \quad$ linear trend, respectively. Results mentioned in (Table 2) reveal that crude fiber concentration was abundent in Acacia jacquemontii $(28.55 \%)$ compared to Capparis deciduas (27.65\%), Ziziphus nummularia (24.50\%), Sesamum indicum (24.05\%), Prosopis juliflora (23.95\%), Simmondsia chinensis (23.80\%), Acacia nilotica (23.45\%), Prosopis cineraria (21.60\%), Salvadora oleiodes (20.80\%), Senegalia senegal (20.35\%), Cordia sinensis (Linn.) (19.90\%),
Cyamopsis tetragonoloba (19.15\%) and Calligonum polygonoides (19.15\%). Results further reveals that although nitrogen free extract in Sesamum indicum, Prosopis juliflora and Simmondsia chinensis varied plant to plant, but no prominent ( $p>0.05$ ) difference existed among them. In contrast to current study, the findings of nitrogen free extract contents in Calligonum polygonoides, Acacia nilotica and Ziziphus nummularia found dissimilar with that of reported studies $[16,22,25]$. However, nitrogen free extract of Prosopis cineraria existed in agreement with that of reported studies of different authors [17, 25, 29]. It could be argued that environment of localities had significant impact on the percent of nitrogen free extract and total carbohydrate contents of different vegetations under present investigation.

Total carbohydrate contents of camel browse vegetations examined in the present investigation are presented in the (Table 2). It was noted that concentration of carbohydrate level was prominently high $(p<0.05)$ in Calligonum polygonoides $(81.19 \%)$ and in Salvadora oleiodes $(45.74 \%)$ it was low. Moreover, in Simmondsia chinensis (79.80\%) and Senegalia senegal (78.99\%) compared to Cyamopsis tetragonoloba (77.58\%), Prosopis cineraria (77.09\%), Acacia jacquemontii (76.95\%), Prosopis juliflora (73.70\%), Ziziphus nummularia (73.45\%), Sesamum indicum (72.00\%), Capparis deciduas (68.57\%), Acacia nilotica (62.62\%) and Cordia sinensis (Linn.) (52.86\%), the concentration level of total carbohydrate was observed significantly $(\mathrm{p}<0.05)$ high. However, the percent of carbohydrate content in Acacia jacquemontii and Cordia sinensis (Linn.) versus Cyamopsis tetragonoloba versus Prosopis cineraria, and Ziziphus nummularia versus Prosopis juliflora did not show any statistical variation $(\mathrm{p}>0.05)$. 
For instance, [27] reported quite relevant results regarding the total carbohydrate level in Prosopis juliflora, while [34] reported little bit different concentration of carbohydrate content in Prosopis cineraria compared to current study. This difference among the results might be related with the variety, environmental distinction and soil composition. Differences in the results could also be related with the sample part of plant as in current study homogenous sample of leaves, seeds, pods were used, while in reported study of [34] only pods were focused.

Total carbohydrate level in Simmondsia chinensis disagreed with the results of [24] who reported lower percent of total carbohydrate content in Simmondsia chinensis contrast to current findings. Findings of [23, 32, 35] disagreed with current results of total carbohydrate of
Acacia nilotica, Capparis deciduas and Haloxylon salicornicum, respectively though appeared totally distinct. Whereas, [26, 29, 36] reported relatively similar total carbohydrate in Cordia sinensis (Linn.), Salvadora oleiodes and Barseem, respectively as recorded in current study. Findings of reported studies regarding crude fiber in Senegalia senegal, Capparis deciduas, Suaeda fruticosa, Prosopis juliflora and Acacia nilotica [15, 21, 25, 29, 37] are quite supportive to the current study. Moreover, percent results of crude fiber content in Cordia sinensis (Linn.), Calligonum polygonoides, Senegalia senegal, Acaciajacquemontii, Ziziphus nummularia, Salvadora oleiodes and Acacia nilotica recorded under present investigation appeared distinct compared to that of reported findings $[13,15,16,20,24,26$, 30].

Table 2. Evaluation of carbohyderate content in camel browse vegetations sampled from Mithi district

\begin{tabular}{|c|c|c|c|}
\hline \multirow{2}{*}{$\begin{array}{c}\text { Camel browse } \\
\text { Vegetations }\end{array}$} & \multicolumn{3}{|c|}{ Dry matter } \\
\cline { 2 - 4 } & Nitrogen free extract (\%) & Crude fiber (\%) & Total (\%) \\
\hline Acacia nilotica & $39.17^{\mathrm{h}}$ & $23.45^{\mathrm{e}}$ & $62.62^{\mathrm{h}}$ \\
\hline Ziziphus nummularia & $48.95^{\mathrm{e}}$ & $24.50^{\mathrm{c}}$ & $73.45^{\mathrm{e}}$ \\
\hline Acacia jacquemontii & $48.40^{\mathrm{ef}}$ & $28.55^{\mathrm{a}}$ & $76.95^{\mathrm{d}}$ \\
\hline Prosopis juliflora & $49.75^{\mathrm{d}}$ & $23.95^{\mathrm{d}}$ & $73.70^{\mathrm{e}}$ \\
\hline Cyamopsis tetragonoloba & $58.43^{\mathrm{b}}$ & $19.15^{\mathrm{j}}$ & $77.58^{\mathrm{d}}$ \\
\hline Cordia sinensis $($ Linn.) & $32.96^{\mathrm{i}}$ & $19.90^{\mathrm{i}}$ & $52.86^{\mathrm{i}}$ \\
\hline Prosopis cineraria & $55.49^{\mathrm{c}}$ & $21.60^{\mathrm{f}}$ & $77.09^{\mathrm{d}}$ \\
\hline Salvadora oleiodes & $24.94^{\mathrm{j}}$ & $20.80^{\mathrm{g}}$ & $45.74^{\mathrm{j}}$ \\
\hline Capparis deciduas & $40.92^{\mathrm{g}}$ & $27.65^{\mathrm{b}}$ & $68.57^{\mathrm{g}}$ \\
\hline Sesamum indicum & $47.95^{\mathrm{f}}$ & $24.05^{\mathrm{d}}$ & $72.00^{\mathrm{f}}$ \\
\hline Senegalia senegal & $58.64^{\mathrm{b}}$ & $20.35^{\mathrm{h}}$ & $78.99^{\mathrm{c}}$ \\
\hline Simmondsia chinensis & $56.00^{\mathrm{c}}$ & $23.80^{\mathrm{d}}$ & $79.80^{\mathrm{b}}$ \\
\hline Calligonum polygonoides & $62.04^{\mathrm{a}}$ & $19.15^{\mathrm{j}}$ & $81.19^{\mathrm{a}}$ \\
\hline LSD $(\mathbf{0 . 0 5})$ & 0.7322 & 0.3055 & 0.7054 \\
\hline SE \pm & 0.3389 & 0.1414 & 0.3265 \\
\hline
\end{tabular}

$\operatorname{LSD}(0.05)=0.1847$

$\mathrm{SE} \pm 0.0855$

\section{Conclusion}

Current study concludes that the environment of Mithi district do not favor the moisture content but support the dry matter, inorganic matter and ether extract contents, whereby Senegalia senegal 
appeared prominently rich in organic matter, Cordia sinensis (Linn.) in total inorganic/mineral matter and Calligonum polygonoides in carbohydrate contents.

\section{Authors' contributions}

Conceived and designed the experiments: AA Khaskheli, GA Mughal \& GB Khaskheli, Performed the experiments: AA Khaskheli \& AA Khaskheli, Analyzed the data: AJ Khaskheli, Contributed reagents/ materials/ analysis tools: AK Lund, TA Kaurejo, M Usman, M Khan \& MA Azeem, Wrote the paper: AA Khaskheli.

\section{Acknowledgement}

Author and co-authors are thankful to the department of Animal Nutrition, Sindh Agriculture University, Tandojam including its all authorized staff members for providing the research facility and conducive environment for conducting the current research project.

\section{References}

1. Anonymous (2006). Economic survey Government of Pakistan, Ministry of Finance, Islamabad.

2. Birhane E, Balehegn $\mathrm{M}$, Kiros $\mathrm{D}$ \& Tsegaye D (2014). Distribution, animal preference and nutritive value of browse species in the Rangelands of Afar, northern Ethiopia. Ethiop J of Bio Sci 3: 135-148.

3. Laudadio V, Tufarelli V, Dario M, Hammadi M, Seddik MM, Lacalandra GM \& Dario C (2009). A survey of chemical and nutritional characteristics of halophytes plants used by camels in Southern Tunisia. Trop Ani Health \& Prod 41: 209-215.

4. Amin AS, Abdoun KA \& Abdelatif AM (2011). Observations on the seasonal browsing and grazing behaviour of camels (Camelus dromedarius) in southern Darfur-Sudan. Res Opinions in Ani \& Vet Sci 1: 213-216.

5. Schwartz HJ, Wolfgang $\mathrm{S} \&$ Isaac $\mathrm{L}$ (2012). Feeding preferences of onehumped camels (Camelus dromedarius) on a semi-arid thornbush savannah in East
Africa - adaptive advantages in view of increasing aridity of the environment, Third International Conference of the Society of Camelid Research (ISOCARD), Muskat, Oman.

6. Kuria SG, Tura IA, Amboga S \& Walaga HK (2010). Forage species preferred by camels (Camelus dromedarius) and their nutritional composition in North Eastern Kenya. Livestock Res for Rural Dev 24: 222-232.

7. El-Keblawy A, Ksiksi $\mathrm{T}$ \& Alqamy $\mathrm{HE}$ (2009). Camel grazing affects species diversity and community structure in the deserts of the UAE. $J$ of Arid Environ 73:347-354.

8. Sultan JA, Rahim IU, Yaqoob M, Nawaz H \& Hameed M (2008). Nutritive value of free rangeland grasses of northern grasslands of Pakistan. Pak J of Bot 40: 249-258.

9. Rifat UKM, Qamar IA, Ahmad S \& Tiwana UA (2016). Seasonal variation in nutritional characteristics of forage species. Basic Res J of Agri Sci \& Rev 6: 21-26.

10. Rasool F, Afzal S \& Saqib A (2018). Chemical composition and uses of Acacia jacquemontii Benth in the Thar district of Pakistan. Bois et Forêts des Tropiques 431: 20-25.

11. Hussain F \& Durrani MJ (2009). Nutritional evaluation of some forage plants from Harboi Rangeland, Kalat, Pakistan. Pak J of Bot 41: 1137-1154.

12. AOAC (2000). Official methods of analysis. Association of Official Analytical Chemists International Maryland., USA.

13. El-Amier YA \& Abdullah TJ (2015). Evaluation of nutritional value for four kinds of wild plants in Northern sector of Nile Delta, Egypt. Open J of Appl Sci 5: 393-402.

14. Chiofalo B, Presti VL, D'Agata A, Rao R, Ceravolo G \& Gresta F (2018). Qualitative profile of degummed guar (Cyamopsis tetragonoloba L.) seeds grown in a Mediterranean area for use as 
animal feed. $J$ of Ani Phys \& Ani Nutri 102: 260-267.

15. Heuzé V, Thiollet H, Tran G, Hassoun P, Bastianelli D, Lebas F (2016). Gum arabic tree (Acacia senegal). Feedipedia, a programme by INRA, CIRAD, AFZ and FAO.

http://www.feedipedia.org/node/342.

Retrived on July 4, 2018, 17:00.

16. Farooq MU, Marwat RUK, Qamar IA, Ahmad S, Razaq A \& Tiwana UA (2018). Seasonal variation in nutritional characteristics of forage species in Rakh Choti Dalana in District Dera Ghazi Khan, Pakistan. Basic Res J Agri Sci and Rev 6: 21-26.

17. Chandra J \& Mali MC (2014). Nutritional evaluation of top five fodder tree leaves of mimosaceae family of arid region of Rajasthan. Inter J of Innov Res Rev 2: 1416.

18. Khanum SA, Yaqoob T, Sadaf S, Hussain M, Jabbar MA, Hussain HN, R Kausar \& Rehman S (2007). Nutritional evaluation of various feedstuffs for livestock production using in vitro gas method. Pak Vet J 27: 129-133.

19. Gull T, Mahmood Z, Anwar F, Sultana B, Nouman W, Shahid SA \& Iqbal MZ (2015). Variation of proximate composition and minerals within different parts of Capparis decidua (Forssk.) Edgew. as a function of harvesting seasons. Pak J of Bot 47: 1743-1748.

20. Samreen U, Ibrar M, Badshah L \& Ullah B (2016). Nutritional and Elemental Analysis of Some Selected Fodder Plants of Darazinda FRDI Khan, Pak Adv P Agri Res 4: 111-127.

21. Abdulrazak SA, Orden EA, Ichinohe T \& Fujihara T (2000). Chemical composition, phenolic concentration and in vitro gas production characteristics of selected Acacia fruits and leaves. Asian Australasian J of Ani Sci 13: 935-940.

22. Towhidi A \& Zhandi M (2007). Chemical composition, in vitro digestibility and palatability of nine plant species for dromedary camels in the province of Semnan, Iran. Egypt J of Biol 9: 47-52.

23. Ashraf MA, Karamat M, Wajid A, Qureshi AK \& Gharibreza M (2013). Chemical constituents of Haloxylon salicornicum plant from Cholistan desert, Bahawalpur, PakJ of Food, Agri \& Enviro 11: 1176-1182.

24. Ullah Z, Baloch MK, Khader JA, Baloch IB, Ullah R, AbdEIslam MN \& Noor S (2013). Proximate and nutrient analysis of selected medicinal plants of Tank and South Waziristan area of Pakistan. Afric J of Pharmacy and Pharmacology 7: 179184.

25. Abdullah M, Rafay M, Sial N, Rasheed F, Nawaz MF, Nouman W, Ahmad I, Ruby $\mathrm{T} \&$ Khalil S (2017). Determination of forage productivity, carrying capacity and palatability of browse vegetation in arid rangelands of cholistan desert (pakistan). Appl Ecol \& Environ Res 15: 623-637.

26. Murray SS, Schoeninger MJ, Bunn HT, Pickering TR, Marlett JA (2000). Nutritional composition of some wild plant foods and honey used by Hadza foragers of Tanzania. J of food comp \& Anal 14: 3-13.

27. Mabrouk H, Hilmi E \& Abdullah M (2008). Nutritional value of Prosopis juliflora pods in feeding nile tilapia (Oreochromis niloticus) fries. Arab Gulf J of Sci Res 26: 49-62.

28. Ravi M (2010). Nutrient composition of important trees from arid zone of Rajasthan. J of Hortic \& Forest 1: 204211.

29. Mohsen MK, El-Santiel GS, Gaafar HMA, El-Gendy HM \& El-Beltagi EA (2011). Nutritional evaluation of berseem. 2. Effect of nitrogen fertilizer on berseem fed as silage to goats. Archiva Zootechnica 14: 21-31.

30. Rasool $F$, Ishaque $M$, Yaqoob $S$ \& Tanveer A (2017). Chemical composition and ethnobotanical uses of Acacia jacquemontii Benth. in the Thal desert in 
Pakistan. Bois et Forêts des Tropiques 331: 1-10.

31. Kathirvel P, \& Kumudha P (2011). Chemical composition of prosopis juliflora (SW.) DC (mosquito bean). Inter J of Appl Biol Pharmac Tech 2: 5-14.

32. Bwai MD, Uzama D, Abubakar S, Olajide OO, Ikokoh PP \& Magu J (2015). Proximate, elemental, phytochemical and anti-fungal analysis of Acacia nilotica fruit. Pharmaceu \& Biol Evaluations 2: 52-59.

33. Towhidi A (2009). Nutritive value of some herbages for dromedary camel in Iran. Pak J of Biol Sci 10: 167-170.

34. Schawn HJ (2001). The biology of the camel. The One-Humped Camel in Eastern Africa, Weikersheim, Verlag Josef Margraf pp 10-29.
35. Rifat UKM, Farooq MU, Qamar IA, Ahmad S, Razaq A \& Tiwana UA (2018). Seasonal variation in nutritional characteristics of forage species in Rakh Choti Dalana in District Dera Ghazi Khan Pakistan. Basic Res $J$ of Agri Sci and Rev 6: 21-26.

36. Malik NS \& K Nath (1970). Chemical composition and nutritive value of green pala (Ziziphus nummularia) leaves. Indon J of Ani Sci 40:41-45.

37. Rathore M (2009). Nutrient content of important fruit trees from arid zone of Rajasthan. J of Hortic \& Forest 1:103108.

38. Ahmad S, Yaqoob M, Hashmi N, Zaman M \& Tariq M (2009). Economic importance of camel: Unique alternative under crisis. Pak Vet J 30: 191-197. 